\title{
GERRIS LACUSTRIS (LINAEUS 1758) AND GERRIS COSTAE (HERRICH-SCHÄFFER 1850) SPECIES - HABITAT RELATIONS ON MOUNTAINOUS TRIBUTARIES OF VIŞEU RIVER (MARAMUREŞ, ROMANIA)
}

\author{
Horea OLOSUTEAN* and Daniela Minodora ILIE **
}

\begin{abstract}
* “Lucian Blaga" University of Sibiu, Faculty of Sciences, Dr. Ion Raţiu Street 5-7, Sibiu, Sibiu County, Romania, RO-550012, mesaje.facultate@yahoo.com

** "Lucian Blaga" University of Sibiu, Faculty of Sciences, Dr. Ion Raţiu Street 5-7, Sibiu, Sibiu County, Romania, RO-550012,iliedf@yahoo.com
\end{abstract}

\begin{abstract}
KEYWORDS: Gerris lacustris, Gerris costae, Vişeu River basin, habitat characteristics.
\end{abstract}

\section{ABSTRACT}

Semi aquatic Heteroptera species from some mountainous tributaries of the Vişeu River were collected and their relations with habitat variables were investigated. Only two species, Gerris lacustris and Gerris costae were found, either one or both species, in almost half of the investigated sampling stations. Correlation analysis between samplings and habitat conditions showed that Gerris lacustris prefers small deep ponds or river banks with steep slopes and is easily adaptable to habitat changes, while Gerris costae is mostly found in large marshes with low, stagnant water and high amounts of vegetation. Both species are relatively tolerant to human impact in their habitat, Gerris lacustris more so. The two species are negatively correlated to each other, as an expression of competition between them. Principal Component Analysis resulted in two dominant factors explaining almost $60 \%$ of the habitat variation, and their graphic representation proved the observed correlations.

ZUSAMMENFASSUNG: Die Art-Habitat-Beziehungen von Gerris lacustris Linaeus 1758 und Gerris costae Herrich-Schäffer 1853 an den montanen Zuflüssen des Vişeu (Maramuresch, Rumänien).

An einigen montanen Zuflüssen des Vişeu wurden die semiaquatischen Heteropteren gesammelt und ihre Beziehungen zu den Habitatbedingungen untersucht. Lediglich zwei Arten, Gerris lacustris und Gerris costae wurden allein oder zusammen an fast der Hälfte der untersuchten Probestellen eingefangen. Die Analyse der Korrelation zwischen den Arten und den Habitatbedingungen zeigten, dass Gerris lacustris kleinere Seen mit größerer Wassertiefe oder die steilen Ufer der Flüsse vorzieht und sich leicht an die Veränderung der Standortbedingungen anpasst, während Gerris costae eher in stehenden Gewässern, und zwar großflächigen Sümpfen mit niedrigem Wasserstand und üppiger Vegetation vorkommt. Beide Arten sind gegenüber menschlichen Eingriffen relativ tolerant, was für Gerris lacustris in verstärktem Maß zutrifft. Die beiden Arten stehen, als Ausdruck ihrer gegenseitigen Konkurrenz, in negativer Korrelation zueinander. Hauptkomponenten analyse (PCA) ergab zwei dominante Faktoren, die fast 60\% der Variation des Habitats erklären, wobei ihre grafische Darstellung die eingangs erwähnten Korrelationen bestätigt. 
REZUMAT: Relaţiile specie-habitat ale speciilor Gerris lacustris Linaeus 1758 şi Gerris costae Herrich-Schäffer 1853 pe afluenţii montani ai Râului Vişeu (Maramureş, România).

$\mathrm{Au}$ fost colectate speciile de heteroptere semiacvatice de pe câţiva afluenţi montani ai Vişeului şi au fost investigate relaţiile acestora cu condiţiile de habitat. Doar două specii, Gerris lacustris şi Gerris costae au fost capturate, singure sau împreună, în aproape jumătate din staţiile verificate. Analiza de corelaţie între specii şi condiţiile de habitat a arătat că Gerris lacustris preferă mici bălţi cu apă adâncă sau malurile abrupte ale râurilor şi se adaptează uşor modificărilor condiţ̧ilor, pe când Gerris costae este mai degrabă găsită în mlaştini de dimensiuni mari, cu apă joasă, stagnantă şi vegetaţie abundentă. Ambele specii sunt relativ tolerante la impactul antropic, cu un plus pentru Gerris lacustris. Cele două specii prezintă o corelaţie negativă una faţă de cealaltă, ca expresie a competiţiei ce le leagă. PCA a rezultat în doi factori dominanţi care explică aproape $60 \%$ din variaţia habitatului, iar reprezentarea lor grafică a confirmat corelaţiile anterioare.

\section{INTRODUCTION}

Gerrids are widely spread epineustonic species, tolerant to habitat conditions changes or low anthropic impact, and easily adaptable to different climatic or geological assemblages (Andersen, 1982). For these reasons, they were collected throughout Romania, mostly on plane and hillside rivers and wetlands (Paina, 1975; Davideanu, 1999; Ilie, 2009; Olosutean et al., 2009), as well as in the Danube Delta (Kiss and Davideanu, 1994; Olosutean and Ilie, 2010). A total of nine Gerrid species have been sampled so far in Romania (Paina, 1975; Davideanu, 1999).

Mountainous rivers are scarcely studied from this group's point of view, mostly because of the relative absence of specific habitats, such as ponds, lakeshores, slow flowing creeks or little bays formed at the shore of rivers (Andersen, 1982; Davideanu, 1999). Therefore, little is known about Gerrid species distribution, habitat preferences or community compositions in such high altitude regions.

Vişeu River, a right side tributary of Tisa River, gathers its waters from a few mountainous areas of the Eastern Romanian Carpathians, before entering in the Maramureş Depression and becoming the largest river of this area. Some of its tributaries, springing from Maramureş Mountains - Socolău, Ruscova and Frumuşaua - and Rodna Mountains Repedea River - were investigated, and the Gerrid species were correlated with habitat variables, in order to point out each species' preferences, following the trend of similar recent date studies (Karaouzas and Gritsalis, 2006; Nosek et al., 2007; Olosutean and Ilie, 2010b; Bloechl, 2010; Skern et al., 2010; Ilie and Olosutean, 2012), presenting a new, more ecologically based approach on the group and opening the discussion of a possible use of this group members as indicators of anthropic intervention in the natural habitats.

\section{MATERIALS AND METHODS}

Two field campaign results are at the base of this study, one from autumn 2007, for the mentioned Maramureş Mountains rivers, 11 sampling points, and one from September 2009, for Repede River, part of the Rodna Mountains, 16 investigated sampling points.

Samplings were similar in all sites, taking into consideration the structure of each station: one single sample of five to ten meters in length was taken, aiming to cover each habitat as much as possible (water surface and body, hygrophilous vegetation where present, station bottom); a standardized 25 minutes/station sampling interval was chosen for both campaigns. 
The samples were collected with an entomological net with a $600 \mathrm{~cm}^{2}$ mesh-size and $1 \mathrm{~mm}$ meshes. Species identification was made by the morphological features, using a stereo binocular, using keys from Poisson (1957) and Davideanu (1999). Species and higher taxa nomenclatures are according to Fauna Europaea (Aukema, 2004).

Relations between these two studied species and habitat characteristics were analyzed using Pearson Correlation Matrix (Pearson, 1896) and Principal Component Analysis (PCA) (Pearson, 1901). The considered habitat conditions were the speed of the water flow, measured in $\mathrm{m}^{3} / \mathrm{s}$, the size of the sampling stations, measured in $\mathrm{m}^{2}$, and water depth, measured in $\mathrm{m}$, to which we added vegetation coverage, estimated as percents of the water surface covered by aquatic or semi aquatic vegetation, and the degree of anthropic impact, again estimated as percents of the station surface affected by any type of visible anthropic influence (garbage, oil marks, wood scraps, lumber, etc.). These variables took part in the correlation matrix formation and in the principal component estimation. Species data, as number of individuals, was added as supplementary variables, in order to determine their position relative to the habitat variables, but in such a way that they do not influence principal component formation. by StatSoft.

Data analysis and graphical interpretation were conducted in STATISTICA v. 8.0

\section{RESULTS AND DISCUSSIONS}

Twenty-seven sampling stations were investigated (Tab. 1), encoded after the river basins: F for Frumuşaua Basin, R for Ruscova Basin (including Socolău, a right side tributary of Ruscova) and Re for Repedea Basin. Only two Gerrid species were collected in 13 of the sampling stations.

Gerris (Gerris) lacustris (Linaeus 1758), the common pond-skater, is the most frequent species among European semi aquatic Heteroptera, found from the border of North Africa and the Caucasus (Lindberg, 1948) up to the vicinity of the Arctic Circle $\left(65.5^{\circ} \mathrm{N}\right.$ Vepsäläinen, 1974). Its wide extension comes from the modesty concerning habitat preferences (Pfenning, 2008) and from its high tolerance to pollution of any kind (Guthrie, 1989). Fifty-eight individuals of the named species were found in ten out of the 27 station that constituted the base for this study.

Gerris (Gerris) costae (Herrich-Schaffer 1853), the moorland pond-skater, is by far a less frequent species than the previous, mentioned by Davideanu (1999) as rare to Romanian fauna. Although mentioned everywhere in Europe (Aukema, 2004), it has fewer sampling sites than G. lacustris, and it seems to prefer colder habitats with less anthropic influence. Because of those preferences, it is known for southern European countries as a mountainous species (Poisson, 1957; Davideanu, 1999), although it is frequent in lowlands in Northern Europe, where the climate is colder (UK National Biodiversity Network, 2011a, 2011b). The species is frequently associated with shallow waters covered by semi-aquatic vegetation, a trademark of the north European moors, hence their popular name. Seventeen G. costae individuals were sampled from six out of the 27 stations investigated on the Vişeu River tributaries. 
Table 1: Gerrid species and habitat characteristics of the sampling stations (Olosutean and Ilie, 2008; 2010).

\begin{tabular}{|c|c|c|c|c|c|c|c|}
\hline \multirow[b]{2}{*}{ Station } & \multicolumn{2}{|c|}{ Species } & \multicolumn{5}{|c|}{ Habitat characteristics } \\
\hline & $\begin{array}{l}\text { G. lacustris } \\
\text { (no. of } \\
\text { individuals) }\end{array}$ & $\begin{array}{c}\text { G. costae } \\
\text { (no. of } \\
\text { individuals) }\end{array}$ & $\begin{array}{l}\text { Flow } \\
\left(\mathrm{m}^{3} / \mathrm{s}\right)\end{array}$ & $\begin{array}{c}\text { Vegetation } \\
\text { (coverage } \\
\% \text { ) }\end{array}$ & $\begin{array}{c}\text { Anthropic } \\
\text { impact } \\
\text { (coverage } \\
\%)\end{array}$ & $\begin{array}{l}\text { Size } \\
\left(\mathrm{m}^{2}\right)\end{array}$ & $\begin{array}{l}\text { Depth } \\
\text { (m) }\end{array}$ \\
\hline F 2 & 2 & - & 0.1 & 50 & 0 & 5 & 0.5 \\
\hline F 3 & 1 & - & 0.3 & 30 & 20 & 5 & 0.3 \\
\hline F 5 & 10 & - & 0 & 10 & 0 & 8 & 1 \\
\hline F 6 & 4 & - & 0 & 70 & 0 & 5 & 0.5 \\
\hline R 2 & 13 & - & 0.3 & 20 & 70 & 2.5 & 0.3 \\
\hline R 4 & 21 & 1 & 0.05 & 80 & 40 & 3.5 & 1 \\
\hline R 5 & 1 & - & 0 & 0 & 90 & 25 & 0.5 \\
\hline $\operatorname{Re} 5$ & 4 & - & 0.3 & 15 & 0 & 6.5 & 0.3 \\
\hline $\operatorname{Re} 6$ & 1 & 1 & 0.2 & 15 & 0 & 6.5 & 0.5 \\
\hline $\operatorname{Re} 7$ & - & 1 & 0 & 60 & 10 & 12 & 0.2 \\
\hline $\operatorname{Re} 8$ & 1 & 1 & 0 & 20 & 50 & 3 & 0.5 \\
\hline $\operatorname{Re} 10$ & - & 4 & 0 & 0 & 30 & 4 & 0.15 \\
\hline $\operatorname{Re} 11$ & - & 9 & 0 & 90 & 0 & 30 & 0.1 \\
\hline
\end{tabular}

The two species share similar features: relative large size (they were part of the former Macrogerris Andersen 1994 subgenus), fast water movement, ambush predatorial feeding (Andersen, 1982), the use of vegetation for sheltering and ovipositioning (Vepsäläinen, 1973), being somehow in competition for the same resources and habitats.

The correlation matrix (Tab. 2) shows sufficient correlation between habitat characteristics, making PCA possible. The highest values, around $37 \%$, are referring to the relations between vegetation presence and anthropic impact, and between station size and the speed of the water flow. It is important that both values are negative, meaning the decrease of one variable at the increase of the other, normal values if we consider that aquatic vegetation is sensible to anthropic impact and that larger stations are mostly lotic.

Table 2: Pearson Correlation Matrix for species and habitat conditions.

\begin{tabular}{|l|c|c|c|c|c|c|c|}
\hline & Flow & Vegetation & $\begin{array}{c}\text { Anthropic } \\
\text { impact }\end{array}$ & Size & Depth & $\begin{array}{c}\text { Gerris } \\
\text { lacustris }\end{array}$ & $\begin{array}{c}\text { Gerris } \\
\text { costae }\end{array}$ \\
\hline Flow & 1.000000 & - & - & - & - & 0.127704 & $\mathbf{- 0 . 3 4 6 8 5 2}$ \\
\hline Vegetation & -0.264246 & 1.000000 & - & - & - & 0.207536 & $\mathbf{0 . 4 0 3 3 7 0}$ \\
\hline $\begin{array}{l}\text { Anthropic } \\
\text { impact }\end{array}$ & -0.017038 & $\mathbf{- 0 . 3 6 9 3 2 1}$ & 1.000000 & - & - & 0.225576 & -0.198191 \\
\hline Size & $\mathbf{- 0 . 3 6 8 7 9 0}$ & 0.227179 & 0.091308 & 1.000000 & - & $\mathbf{- 0 . 3 5 4 8 1 0}$ & $\mathbf{0 . 5 9 8 0 1 8}$ \\
\hline Depth & -0.209894 & 0.009528 & 0.038736 & -0.280527 & 1.000000 & $\mathbf{0 . 6 8 1 5 2 7}$ & $\mathbf{- 0 . 4 5 4 2 3 8}$ \\
\hline
\end{tabular}


As for the species $G$. lacustris, presents a very high positive correlation with the water depth, and a quite significant negative correlation with station size, meaning it prefers small ponds with relatively high depth; the other variables do not seem to be of importance for the species' distribution, but it is important that all correlations, excepting the one with station size, are positive, in other words, the species is somehow favoured by an increase in the speed of the flow, in the vegetation covering or in the anthropic impact, proving its well known adaptability.

G. costae is much more habitat constricted than its relative: four out of five variables influence in different degrees the species' distribution, the highest correlation being a positive one with the station size, seconded by a negative one to the station's depth; if we add the relatively high positive correlation to vegetation coverage and the similar negative correlation to the speed of the water flow, we can state that the named species prefers large, highly vegetated marshes, where the low water depth and slow current are perfect for the ambush predator it is. Out of our variables, the anthropic impact is the only one not influencing the distribution (probably the larger stations preferred by the species offer enough clean space for its individuals).

PCA performed on the given variables resulted in five Eigenvectors (Tab. 3). The first two factors (highlighted columns for table number 3 ) are responsible for $57.4 \%$ of the entire variation, therefore being the most important of them. The first factor is strongly and positively correlated with vegetation coverage and station size, and negatively correlated to flow speed, while the second factor is positively correlated to water depth, and presents strong negative correlations to anthropic impact or station size.

Table 3: Eigenvectors of the Correlation Matrix.

\begin{tabular}{|l|c|c|c|c|c|}
\hline & $\begin{array}{c}\text { Factor 1 } \\
\mathbf{( 3 2 . 2 9 \% )}\end{array}$ & $\begin{array}{c}\text { Factor 2 } \\
\mathbf{( 2 5 . 1 1 \% )}\end{array}$ & $\begin{array}{c}\text { Factor 3 } \\
(23.87 \%)\end{array}$ & $\begin{array}{c}\text { Factor 4 } \\
(10.58 \%)\end{array}$ & $\begin{array}{c}\text { Factor 5 } \\
(8.15 \%)\end{array}$ \\
\hline Flow & $\mathbf{- 0 . 5 4 3 5 0 6}$ & 0.118198 & $\mathbf{0 . 5 0 5 3 9 1}$ & 0.437749 & -0.493545 \\
\hline Vegetation & $\mathbf{0 . 5 8 7 9 9 1}$ & 0.350637 & 0.124517 & $\mathbf{0 . 6 9 5 1 4 5}$ & 0.180524 \\
\hline $\begin{array}{l}\text { Anthropic } \\
\text { impact }\end{array}$ & -0.262962 & $\mathbf{- 0 . 6 4 4 5 4 7}$ & -0.389238 & $\mathbf{0 . 5 5 7 2 9 3}$ & 0.230930 \\
\hline Size & $\mathbf{0 . 5 3 4 2 3 4}$ & $\mathbf{- 0 . 5 3 3 2 6 0}$ & 0.092804 & -0.031097 & $\mathbf{- 0 . 6 4 8 5 7 4}$ \\
\hline Depth & -0.065670 & $\mathbf{0 . 4 0 4 0 7 4}$ & $\mathbf{- 0 . 7 5 4 2 9 2}$ & 0.116647 & -0.499848 \\
\hline
\end{tabular}

The graphic representation of the species and habitat variables in relation to the first two factors is depicted in figure number 1 . The strong positive correlation between $G$. lacustris and water depth, and G. costae and station size and vegetation coverage, already discussed, are visible here, as well as the negative one between G. costae and flow speed, or the negative one between $G$. lacustris and station size.

Also, an important mention is that the two studied species seem to be negatively correlated to each other, an expression of the competition between them for similar resources, especially on small size stations. 


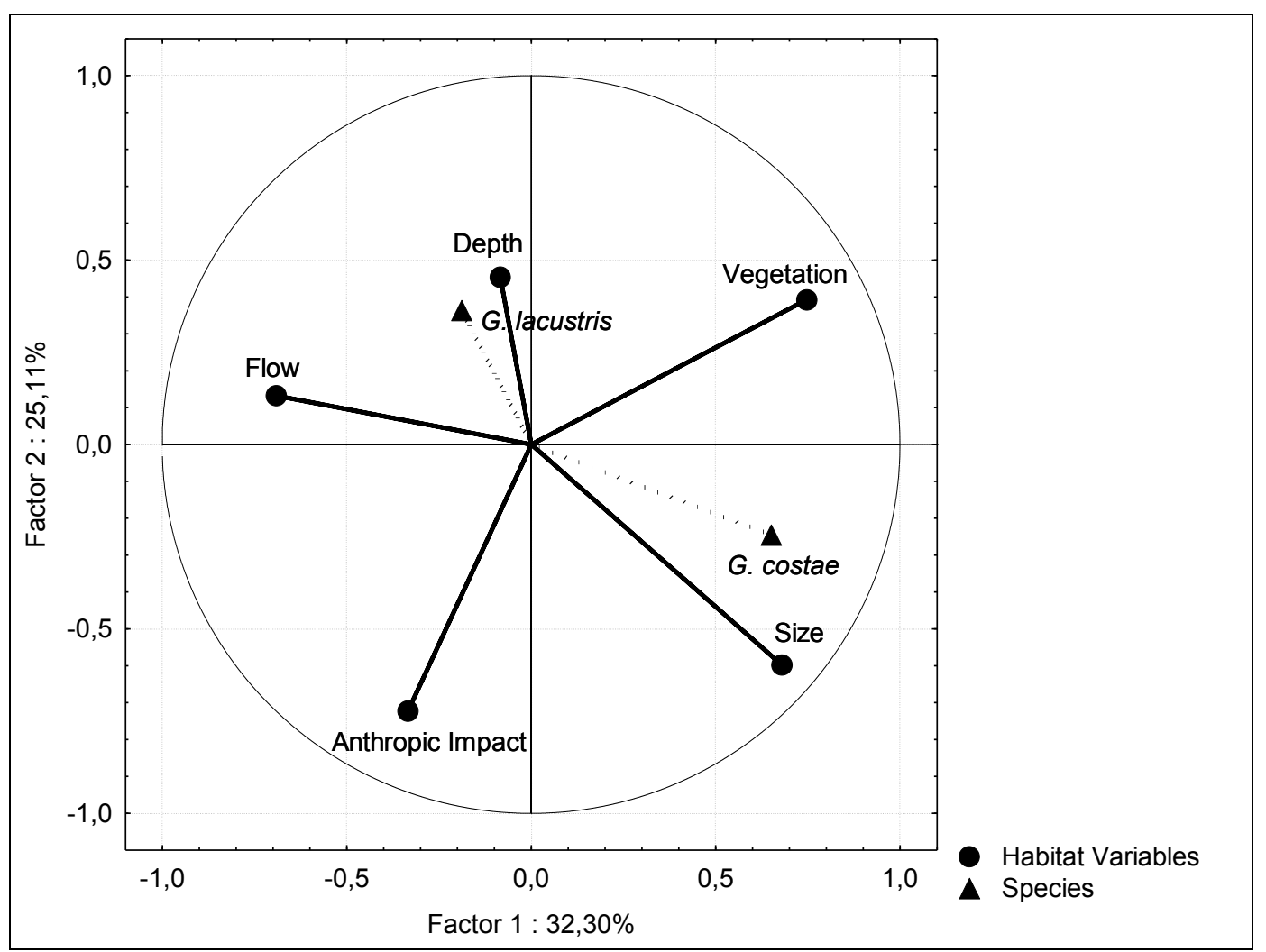

Figure 1: PCA biplot of the collected species in relation to habitat conditions.

The relations between habitat variables and species distribution is not exactly matching previously published data, at least for G. lacustris. In that order, Nosek et al. (2007) found Aquarius paludum (Fabricius 1794) as the dominant Gerrid, and G. lacustris of secondary importance regardless of habitat conditions, Skern et al. (2010) found $G$. lacustris dominant and correlated with shore semi aquatic vegetation and shade, but indifferent to aquatic vegetation, while we previously found the species dominant in small stations, alone or associated with aquatic Heteroptera, regardless of habitat characteristics (Olosutean and Ilie, 2010b; Ilie and Olosutean, 2012).

This can lead to the conclusion that species-habitat relations are not constant for $G$. lacustris, being more of a local trade-mark, and there is a consistent possibility that they can change with the season or even from one year to another. In that order, large scale studies, on both time and space coordinates, are indicated, before coming up with a general conclusion regarding this aspect.

\section{CONCLUSIONS}

Only two of the nine Gerrid species of Romania are adaptable enough to inhabit high latitude studied mountainous regions. The two species are a known cold habitat species, Gerris costae, and the most adaptable and wide spread semi aquatic Heteroptera, Gerris lacustris. 
Not all suitable habitats for the group are occupied by Gerrids, only 13 out of 27 investigated stations (less than 50\%) presents members of this group. However, high altitudes are not very favourable in Romania for high densities and diversity of the group's members (Ilie, 2009; Olosutean and Ilie, 2008, 2010a, 2010b).

Gerris lacustris shows a strong positive correlation with water depth and negative correlation with station size, expressing a preference for small, deep puddles or steep river banks; all the other variables were slightly positive correlated with the species, proving once again its high adaptability and its high tolerance to ever-changing habitats.

Gerris costae is much more habitat dependent, presenting strong correlation with four habitat variables: positive correlations with size and vegetation presence, and negative ones with flow speed and water depth, proving its preference for large marshes or low depth puddles, where vegetation grows abundant and the water is almost stagnant. Its slight negative correlation with anthropic impact presents it as much more sensible to this factor than its relative, but still able to resist at low human interferences.

Correlations of different degrees are present between the habitat variables taken into concern for the present study, allowing their decomposition into fewer principal components. The first two obtained factors are representing almost $60 \%$ of the habitat variation. The graphical representation of those two factors confirms all correlation presented above.

The results are not identical to other similar studies made on this group, revealing a local specificity of the area. Even more, it seems that relations between habitat and community composition or species distribution vary for at least some semi aquatic Heteroptera from one area to another, proving the necessity for extended further studies in this field of interest.

\section{REFERENCES}

1. Andersen N. M., 1982 - The semiaquatic bugs (Hemiptera, Gerromorpha) phylogeny, adaptations, biogeography and classification, Scandinavian Science Press Ltd., 445.

2. Aukema B., 2004 - Fauna Europaea: Heteroptera - Nepomorpha, Fauna Europaea version 1.1, http://www.faunaeur.org.

3. Bloechl A., Koenemann S., Philippi B. and Melber A., 2010 - Abundance, diversity and succession of aquatic Coleoptera and Heteroptera in a cluster of artificial ponds in the North German Lowlands, Limnologica, 40, 215-225.

4. Davideanu A., 1999 - Contribuţii la studiul heteropterelor acvatice din România, PhD thesis, unpublished.

5. Guthrie M., 1989 - Animals of the surface film, Slough, Richmond, 92.

6. Ilie D. M., 2009 - Heteropterele acvatice şi semiacvatice (Heteroptera, Nepomorpha, Gerromorpha) din bazinul mijlociu al Oltului, Ed. Altip, Alba Iulia, 279. (in Romanian)

7. Ilie D. M. and Olosutean H., 2012 - Aquatic and semi aquatic Heteroptera communities from south-east Transylvanian small rivers, Travaux du Muséum National d'Histoire Naturelle “Grigore Antipa”, 55(2), 206-217.

8. Karaouzas I. and Gritsalis K. C., 2006 - Local and regional factors determining aquatic and semi-aquatic bug (Heteroptera) assemblages in rivers and streams of Greece, Hydrobiologia, 573, 199-212.

9. Kiss B. and Davideanu A., 1994 - Heteroptere acvatice şi semiacvatice din Rezervaţia Biosferei Delta Dunării, Analele Ştiinţifice ale Institutului Deltei Dunării, 3, 149-154. (in Romanian) 
10. Lindberg H., 1948 - Zur kenntnis der insektenfauna im brackwasser des Baltischen Meeres, Societas Scientiarum Fennica, Commentationes Biologicae, 10, 1-206. (in German)

11. Nosek J. N., Vásárheli T., Bakonyi T. and Oertel N., 2007 - Spatial pattern of waterbugs (Gerromorpha, Nepomorpha) at different scales in the Szigetköz (Hungary), Biologia, 62(3), 345-350.

12. Olosutean H. and Ilie D. M., 2008 - Aspects regarding the diversity of aquatic and semiaquatic Heteroptera from Maramureș Mountains Nature Park, Transylvanian Review of Systematical and Ecological Research, Curtean-Bănăduc A. et al., (eds), 5, 63-73.

13. Olosutean H., Ilie M. D., Axinte S. and Drăgoiu A., 2009 - Biodiversity analisys on aquatic and semiaquatic Heteroptera (Heteroptera, Nepomorpha - Gerromorpha) from two Transylvanian (Romania) lake complexes, Acta Oecologica Carpatica, II, 141-148.

14. Olosutean H. and Ilie D. M., 2010a - Influence of anthropic impact on aquatic and semiaquatic Heteroptera distribution from Repede River (Rodna Mountains National Park), Transylvanian Review of Systematical and Ecological Research, Curtean-Bănăduc A. et al., (eds), 9, 149-158.

15. Olosutean H. and Ilie D. M., 2010b - Relationships between habitat characteristics and aquatic and semi aquatic Heteroptera community structure in Romanian mountainous regions: a preliminary report, Romanian Journal of Biology - Zoology, 55(2), 139-148.

16. Paina M. I., 1975 - Lista heteropterelor acvatice şi semiacvatice (Order Heteroptera) din R. S. România, Nymphaea, III, 99-115. (in Romanian)

17. Pearson K., 1896 - Mathematical contributions to the theory of evolution III: Regression, heredity and panmixia, Philosophical Transactions of the Royal Society A, 187, 253-318.

18. Pearson K., 1901 - On lines and planes of closest fit to systems of points in space, Philosophical Magazine, 2(6), 559-572.

19. Pfenning B., 2008 - Seasonal life-history adaptation in the water strider Gerris lacustris, $P h$. D. Thesis, Julius Maximilians Universität, Würzburg.

20. Poisson R., 1957 - Faune de France: Hétéroptères aquatiques, Librairie de la Faculté de Sciences, Paris, 265. (in Frech)

21. Skern M., Zweimüller I. and Schiemer F., 2010 - Aquatic Heteroptera as indicators for terrestrialisation of floodplain habitats, Limnologica, 40(3), 241-250.

22. United Kingdom National Biodiversity Network, Aquatic Heteroptera recording scheme, 2011 - Aquatic Heteroptera Dataset (accessed through GBIF data portal, http://data.gbif.org/datasets/resource/960, 2011-02-11)

23. United Kingdom National Biodiversity Network, Biological Records Centre, 2011 - Water Bug (aquatic Heteroptera) data for Britain (accessed through GBIF data portal, http://data.gbif.org/datasets/resource/942, 2011-02-11)

24. Vepsäläinen K., 1973 - The distribution and habitats of Gerris Fabr. species (Heteroptera, Gerridae) in Finnland, Annales Zoologica Fennici, 10, 419-444.

25. Vepsäläinen K., 1974 - The life cycles and wing lengths of Finnish Gerris Fabr. (Heteroptera, Gerridae), Acta Zoologica Fennica, 141, 1-73. 